\title{
Gastric Cancer pT4a TNM Finding v7
}

National Cancer Institute

\section{Source}

National Cancer Institute. Gastric Cancer pT 4a TNM Finding v7. NCI Thesaurus. Code C89840.

Gastric cancer with tumor invading serosa (visceral peritoneum). (from AJCC 7th Ed.) 